Informatika i sistemy upravleniya. - 2017. - No. 4(54). - P. 74-80.

Egorov A.V., Smoliakova G.P., Egorov V.V. (naukakhvmntk@mail.ru), Pashentcev Ia.E. The Khabarovsk branch of the State Institution Eye Microsurgery Complex named after S.N. Fyodorov

\title{
METHOD FOR PROGNOSIS OF VISUAL FUNCTIONS AFTER ENDOVITREAL SURGERY OF RHEGMATOGENOUS RETINAL DETACHMENT WITH AN ANATOMIC EFFECT
}

The present research was conducted on a group of patients with rhegmatogenous retinal detachment in order to realize predictability by the method of multiple linear regression of visual functions after surgical treatment. The effectiveness of the obtained forecasting method was confirmed in a sample of the patients group.

Keywords: rhegmatogenous retinal detachment, prognosis of visual functions, multiple linear regression, regression remains analysis.

DOI: $10.22250 /$ isu.2017.54.74-80

For citation:

Egorov A.V., Smoliakova G.P., Egorov V.V., Pashentcev Ia.E. METHOD FOR PROGNOSIS OF VISUAL FUNCTIONS AFTER ENDOVITREAL SURGERY OF RHEGMATOGENOUS RETINAL DETACHMENT WITH AN ANATOMIC EFFECT // Informatika i sistemy upravleniya. - 2017. No. 4(54). - P. 74-80. 